\title{
The English Catholic Church and the Age of Mercantilism: Bishop Richard Challoner and the South Sea Company
}

\author{
Giada Pizzoni \\ University of Exeter \\ G.pizzoni@exeter.ac.uk
}

\begin{abstract}
This article argues that the commercial economy contributed to sustain the English Catholic Church during the eighteenth century. In particular, it analyzes the financial dealings of Bishop Richard Challoner, Vicar Apostolic of the London Mission (1758-1781). By investing in the stock market, Challoner funded charitable institutions and addressed the needs of his church. He used the profits yielded by the Sea Companies for a variety of purposes: from basic needs such as buying candles, to long-term projects such as funding female schools. Bishop Challoner contributes to a new narrative on Catholicism in England and enriches the literature on the Mercantilist Age. The new Atlantic economy offered an opening and Catholics seized it. By answering the needs of the new fiscal-state, the Catholic Church ensured its survival, secured economic integration, and eventually achieved political inclusion.
\end{abstract}

\section{Keywords}

English Catholic Church - economy - mercantilism - South Sea Company - Richard Challoner

\section{Introduction}

The years between the 169 os and the 178 os were ones of revolutions in Britain; some more "glorious" than others, but all ushering a new age in the country's 
politics, society and economy. ${ }^{1}$ The country saw the rise of mercantilism, the emergence of free trade that allowed merchants to prosper, and major changes to the church which reinvented itself alongside the newly emerging nation. It was a time in which the country shaped its own confident identity socially and nationally and when Parliament became the symbol of the nation as a permanent assembly with the power to tax and raise money on credit. Power was still based on land, as the Whig adage went "liberty and property," but now wealth could also be accumulated through trade which was virtually untaxed. It was a time of economic enterprise and financial innovations, ushered in by the age of mercantilism where moral and individual ties loosened over transnational exchanges. But most importantly it was a time in which the Church of England became an "institution," and by not acknowledging the postrevolutionary regime of William of Orange, it untied itself from the government and the Crown that had legitimated its very existence, ultimately losing the monopoly on belief. It was this new time of profound crisis that offered Catholics the opportunity to renegotiate their role in English society. Officially, open believers were still being prosecuted, but in reality the penal laws usually remained unenforced. ${ }^{2}$ It was a time in which being a Jacobite did not mean being Catholic and being Catholic did not prevent one feeling British. ${ }^{3}$ Richard Challoner and his community situated themselves in this age of crisis, seizing the opportunities that the new mercantile economy offered and embracing economic inclusion to eventually ensure their relief in 1778 , just as the age of mercantilism came to an end.

In this new era, the English Catholic Church was an institution under great pressure, striving for its survival within a Protestant country while also battling financial strains and adverse policies. Scholars have provided compelling analysis on the religious and political context from this time but have so far failed to address both the importance of the emerging commercial economy as a factor in its survival and the equal involvement of the Church in contributing to commercial expansion. ${ }^{4}$ In his seminal work on the English Catholic com-

1 John Carswell, From Revolution to Revolution: England 1688-1776 (London, 1973). Carl Wennerlind, Casualties of Credit, The English Financial Revolution, $1620-1720$ (London, 2011).

2 Carswell, From Revolution to Revolution, 32-33.

3 Gabriel Glickman, "A British Catholic Community? Ethnicity, Identity and Recusant Politics, 166o-175o," in Early Modern English Catholicism, Identity, Memory and Counter-Reformation, ed. by Kelly J.E. and Royal S. (Leiden, 2017), 6o-81. David Parrish, Jacobitism and Anti-Jacobitism in the British Atlantic World, 1688-1727 (Woodbridge, 2017), 38-65.

4 Gabriel Glickman, The English Catholic Community, 1688-1745, Politics, Culture and Ideology (Woodbridge, 2009): Glickman has focused on investments in industry and trade. Antoin E. Murphy, Richard Cantillon, Entrepreneur and Economist (Oxford, 1986), 1-9: Cantillon's family was involved in trade and banking. Peter Marshall and Geoffrey Scott, 
munity, John Bossy briefly mentions investments of the Church in New South Sea annuities and London stocks but concludes that these practices were not successful and that the money was mainly lost-suggesting that the Church played only a marginal role in the mercantile economy. ${ }^{5}$ However, a thorough investigation of his accounts instead suggests that the Church helped finance the stock market and specifically the South Sea Company with investments that fuelled exploration and expansion while also sustaining a strained institution. More than anything the records highlight the role played by English Catholics as the economic instruments of the government, suggesting engagement and inclusion which ultimately led to the acknowledgement of their role as accepted citizens.

Everything about the age of mercantilism encompasses the economic and financial changes which swept Britain in the 165 os and the 178 os. ${ }^{6}$ It is an age that started with the idea of trade as a zero sum game, implying fierce competition, monopolies and warfare among the European nations at a time when wealth and power were based solely on land and resources and were therefore limited. However, a century of international trade completely revolutionized this model and what had started as an age of monopolies concluded as one of free trade. It was the elaboration of a rational economic thought and a belief in trade and manufacturing as generator of wealth; wealth that became intangible and unstable, but with virtually unlimited resources. Mercantilism produced a society in which whoever "had the money had the management." The old economic agrarian structure foundered and the newly emerging

Catholic Gentry in English Society: The Throckmortons of Coughton from Reformation to Emancipation (Burlington, 2009): this work mentions some form of capital enterprise of the gentry. John Bossy, The English Catholic Community $1570-1850$ (London, 1975). J.C.H. Aveling, The Handle and the Axe: The Catholic Recusants in England from Reformation to Emancipation (London, 1976), 291.

5 Bossy, The English Catholic Community 1570-1850, 246-247. The funds ranged between £6oo and $£ 2$,ooo.

6 Steve Pincus, "Rethinking Mercantilism: Political Economy, the British Empire, and the Atlantic World in the Seventeenth and Eighteenth Centuries," The William and Mary Quarterly, 69 (2012): 3-34.

7 Henry Roseveare, The Financial Revolution 1660-176o (London, 1991), 46. Murphy, A.L., The Origins of English Financial Markets, Investment and Speculation before the South Sea Bubble (Cambridge, 2009). 
economy with its financial means offered plenty of opportunities to whoever was willing to adapt.

Indeed, this century saw a revolution in commerce but most of all a revolution in finance. The 169os in particular witnessed reorganization of the relatively unsophisticated market in shares and stocks: ${ }^{8}$ the Financial Revolution which created the basis for the modern financial power of Britain. The almost twenty years of warfare against Louis XIV had left England's finances fraught, and a solution was found in making the public liable for the debt. Indeed, in the 168 os there were no more than fifteen joint stock companies in the hands of around one-thousand individuals in London. In over a decade, more than one-hundred companies emerged together with a class of stock jobbers and brokers. Among all these companies, the most successful were the Bank of England, the New East India Company (which reorganized the old one in 1698) and the newly created South Sea Company. ${ }^{9}$ The Bank of England was created in 1694 when the war debt was nationalized, and it proved highly successful in raising money. But the East India Company had a different nature entirely. It had been created in its old form during Elizabethan times to control the Eastern trade, and since its inception had pursued an aggressive commercial policy. After the Glorious Revolution, due mainly to its close associations with the Stuart kings, it was forced to restructure itself and to loosen its monopoly, leading to the creation of the New Company in $1698 .{ }^{10}$ But things did not run smoothly as the new business immediately faced problems over control of the lucrative East Indian trade, and a merger between the two companies was constantly discussed. Investment in the company was potentially lucrative but the shares were held by a very small minority which ran it as a sort of plutocracy.11 Finally, the South Sea Company was something of a mix between the other two: a product of mounting war debt created in 1711 by the Tory government in order to organize the national debt and exploit the public credit after twenty years of expensive warfare through a trade monopoly. ${ }^{12}$ During negotiations with France and Spain, England hoped to acquire control of the slave trade with Spanish America, the "South Seas." The contract, the asiento, was to last for thirty years during which the English would supply 4,800 slaves per year. This target was never met as acquiring supplies had become problematic due

\footnotetext{
8 Roseveare, The Financial Revolution 1660-1760; Wennerlind, Casualties of Credit.

$9 \quad$ Murphy, The Origins of English Financial Markets, 220.

10 Furber Holden, Rival Empires of Trade in the Orient, 1600-1800, Europe and the World in the Age of Expansion (Oxford, 1976), 185-229.

11 P.G.M. Dickson, The Financial Revolution in England, A Study in the Development of Public Credit, 1688-1756 (London, 1967), 249-303.

12 Wennerlind, Casualties of Credit, 161-215.
} 
to an inability to keep the monopoly over this trade and besides, the Spanish could not be trusted to keep their promises as customers. ${ }^{13}$ Trade was not as profitable as had been promised, but the lure of the Atlantic riches still attracted investors. In 1720, due to mismanagement, inflated debt and propagandistic lies, the South Sea Company burst, wiping away fortunes and forcing a harsh lesson upon the English economy. Demands for competency and regulation ensued and the company was reorganized: its capital was split in two, one half representing the trading capital with which the company continued trading with South America until 175 o and the rest a permanent liability on which the Exchequer paid modest interests and remained in place until 1850. ${ }^{14}$ Whether the company made any profits is unclear, but nevertheless, it managed to control 20 percent of the English slave trade and see its own ships return home laden with dyestuffs, sugar, and bullion. Historians continue to disagree, but whatever the reality of the time, the propaganda machines continued to convince investors that Atlantic trade offered unlimited riches, with utter disregard for its inhumanity, and the company survived for over one-hundred years.

The East India Company, the South Sea Company and the Bank of England were the three most popular investment opportunities offered to the eighteenth century public. Investors varied in social status, being predominantly merchants and landowners, but also included members of the clergy, civil servants, and religious minorities. In terms of gender, women had a non-negligible role representing 6 percent of the stock holders. Women provided capital and possessed a sizeable part of the market, acknowledging the value of holding stock as a long-term investment. ${ }^{15}$ Among dissenters, Catholics also contributed as ultimately the British government needed funds and was not concerned with the identity or religion of vital moneylenders. It was this ability to adapt and seize opportunities that would allow the Catholics to become a part of the economy, yet within the literature on English finance in the eighteenth century, there is almost no mention of Catholic stock holders. Dickson in his study of the English Financial Revolution acknowledges various religious minorities as the owners of government debt. At this time non-Anglicans were still subject to penalties, such as exclusion from public offices, military, or civil

\footnotetext{
13 Wennerlind, Casualties of Credit. The Royal African Company was unable to control the monopoly over the slave trade, effecting supplies.

14 Roseveare, The Financial Revolution 1660-176o; Julian Hoppit, "The Myths of the South Sea Bubble," Transactions of the RHS 12 (2002): 141-165; and Wennerlind, Casualties of Credit, 197-234.

15 Murphy, The Origins of English Financial Markets, 202; A. Laurence, "Lady Betty Hastings, Her Half-sisters, and the South Sea Bubble: Family Fortunes and Strategies," Women's History Review 15, no. 4 (2006): 533-540.
} 
careers, and as a consequence, they diverged their interests in commerce and finance. Dickson specifically identifies Huguenots and Sephardic Jews yet still dismisses them as irrelevant investors and disregards Catholics altogether. ${ }^{16}$ Among dissenters, Dickson argues that the Anglican clergy purchased government bonds as they had no scruples about benefiting from such financial operations. Here, through the stock market, clergymen supported charities in a practice common among various organizations, not just the Church of England. ${ }^{17}$ Indeed, philanthropic societies invested bequests in annuities and bonds to provide their charities with regular income. ${ }^{18}$ For the most part, South Sea Company stocks were used to support foundations and endow schools and hospitals; having low fixed-interest rates meant that investing carried low risk on top of the government acting as a guarantor for payment. This made the investments ideal for organizations not interested in speculation. Nevertheless, scholars largely agree that the Catholic clergy did not invest similarly because of the ban on Catholics lending money. Only in Walsh's work on Ireland and the South Sea bubble has the concept of Catholic investors been introduced, although again only with a marginal role..$^{19}$

The evidence of Richard Challoner and his community therefore allows for new insight on eighteenth-century English Catholicism. As Vicar Apostolic of the London Catholic Mission from 1758 to 1781 he became one of the leading figures of his Church. His life and work are well known among Catholic historians, but no one has yet looked at his financial papers, instead focusing on his role as spiritual leader and religious writer. ${ }^{20}$ His work record offers an opportunity to finally fully understand the role of English Catholics within the British economy. Equally it shows how the financial market offered further opportunities to the community and how Catholics mastered the new means offered by the new fiscal military economy, tackling political impairment through economic integration. The Catholic community simply adopted a system already in place and being widely used by the Protestant organizations and, through

16 Dickson, The Financial Revolution in England, 306: Among the stockholders there were religious minorities including Huguenots and Jews. They invested in the first government long-term loan, but also in the Bank of England. Foreign investments would become more significant after 1713, with money put in Bank stock or East India stock.

17 Helen J. Paul, The South Sea Bubble, An Economic History of its Origins and Consequences (New York, 2011), 54-74, 107. For instance, the Royal Society was among the subscribers.

18 Donna T. Andrew, Philanthropy and Police: London Charity in the Eighteenth Century (Princeton, 1991), 79.

19 Patrick Walsh, The South Sea Bubble and Ireland, Money, Banking and Investment, 1690-1721 (Woodbridge, 2014).

20 Eamon Duffy, Challoner and his Church: A Catholic Bishop in Georgian England (London, 1981), 1-26. 
the stock market, was able to both serve its own purposes and those of the British government to contribute to its inclusion and endurance.

Richard Challoner was officially appointed Vicar Apostolic of the London District in 1758, and his papers offer unique insight into the life of his community. He was born in Lewes, East Sussex, in 1691. His father was a Protestant "wine-cooper," and his mother was a Catholic housekeeper, firstly in the Gages' household in Firle, and later in Lady Holman's mansion in Warkworth, where Challoner converted to Catholicism. In 1705, Challoner moved abroad to be educated in the English College in Douai, returning to England only in 1730 where he became known as "the Venerable"; a master of spirituality, deeply involved in helping the poor and in administering charity. ${ }^{21}$ In the mid-eighteenth century he was deemed responsible for a Catholic revival following the dire times of the Jacobite rebellions in 1715 and $1745 .{ }^{22}$ In London, Challoner joined the English Catholic Mission where he would stay for more than forty years and in 1741, was consecrated as a bishop and appointed as assistant to Bishop Benjamin Petre-Vicar Apostolic of the London District from 1734 until $175^{8}$. Upon Challoner's appointment, Petre almost immediately resigned himself from his duties, leaving his assistant to cope with the administration of the District. This saw Challoner taking charge of the office. ${ }^{23}$ Appointed with almost twenty years of experience, he had invaluable insight into the needs of the Church which enabled him to begin a complete overhaul of how the system was run.

In order to fully grasp the significance of Bishop Richard Challoner and his impact within this position, it is important to discuss the Catholic Church in England. English Catholics at this time were part of a Mission established by Rome in 1688. The Holy See divided the English territories into four districts:

21 J.C.H. Aveling, The Handle and the Axe, 291. L.E. Whatmore, "The Birthplace and Parentage of Bishop Challoner: An Enquiry," Recusant History 4 (1973): 254-26o; David Mathew, Catholicism in England, 1535-1935 (London, 1936), 135-139; and Eamon Duffy, Challoner and his Church.

22 Aveling, The Handle and the Axe, 253-283.

23 Edward Norman, Roman Catholicism in England, from the Elizabethan Settlement to the Second Vatican Council (Oxford, 1985), 52-54; (Westminster Diocesan Archive) WDA, register A 41, folio 136, Breve Relazione dello Stato della Religione Cattolica in Inghilterra (short report about Catholicism in England). In 1759, James Talbot, brother of the Earl of Shrewsbury, was appointed as Challoner's assistant. 
Northern, London, Western, and Midland. The London District consisted of ten southern counties; the Channel Islands and, in the eighteenth century, the British possessions in North America as well as some West Indian islands. ${ }^{24}$ There were at this time most likely the same number of Catholics in London as in America, predominantly in Maryland and Pennsylvania and later in Virginia and New Jersey. In these American colonies the Jesuits ran the Mission, although formal responsibility lay always with the London Vicar. ${ }^{25}$

In the Catholic Mission in England, the Holy See granted four bishops with the authority of vicars; their powers were renewed every five years with each being responsible for his own district and none being able to interfere in the others' jurisdiction. When Challoner arrived in the early thirties, the Mission was not well structured, but he introduced coherence and organization and was the first bishop to visit his district, firstly in 1741 and twice again in 1749 and 1753. His reports allow us to understand how the community fared and how Catholics engaged with the economic life of the Empire. Records show that during the visitations, Challoner noticed a decrease in the size of his congregation, but he asserted that this was in fact less than would be expected from such a "corrupt century" where "the faith is weak and charity languishes." 26

Embracing his new position as Vicar, Challoner remained well aware of the social and political position of Catholicism within the country. Officially,

24 (Westminster Diocesan Archive) WDA, register B 1536, Challoner's Ledger: In October 1768, Challoner wrote to a missionary in the West Indies that the Holy See had assigned them the islands ceded by the French to the English. He wanted help from Rome because the remote nature of the lands made difficult to provide for the faithful there.

25 Aveling, The Handle and the Axe, 150: After the acquisition of Canada, Florida, and the West Indies, Challoner considered a new Vicar Apostolic for those lands; however, the first Bishop was only appointed after the War of Independence.

26 WDA, A 41, folio 136: The Breve Relazione of 1774, about the status of Catholicism in England, highlighted persecution the Catholic community endured. Although biased, the document estimated 100,000 Catholics in the country, with 20,000 in London alone; Mary K. Kinoulty, A Social Study of Roman Catholicism in West Sussex in the Eighteenth Century (M.A. Thesis, W.s.R.O., Chichester, 1985), 28-32: The Catholic presence was more consistent in the northern provinces, especially in the county of Lancashire where there were few peers of the kingdom. In the London District, which included ten counties in the south of England, the majority of the population was involved in agriculture or domestic services. Particularly in Sussex, the community depended on a precarious living, with fortunes bound up to the quality of the harvest. It is for this reason that the households of rich families represented the major sources of employment. Servants were predominantly Catholic, but few converts suggested that Protestants were not completely excluded; Duffy, Challoner and his Church, 6-7: In 1730, in the London District, there were roughly 20,00o Catholics, whose social backgrounds varied widely. The greatest concentrations of Catholics were in the east and south of London. 
Catholics were still routinely prosecuted for their beliefs. ${ }^{27}$ The community differed in economic resources, due in part to the double land tax and civil disabilities which prevented individuals receiving incomes from public offices. However, they clung to their faith with tenacity and adapted to the new commercial economy in which landowning was no longer profitable. Instead, Catholics modernized their estates by investing in technology, agriculture, and the mining sector. ${ }^{28}$ They knew their survival depended on reinventing themselves as either merchants or men of business, and so they evolved, becoming shrewd observers of the new financial innovations of the British economy. ${ }^{29}$

In the 176 os, in one of his many reports to Rome, Challoner reported deep concerns for his Mission. Despite the fact that Catholics were no longer openly prosecuted, they were forced to practice intra privatos parietes. ${ }^{30}$ "Times were

27 Glickman, The English Catholic Community, 59-64; Kinoulty, A Social Study, 41, 57; Bernard Ward, The Dawn of the Catholic Revival in England 1781-1803 (London, 1909), 2: Attending a Protestant service was compulsory at least once a month, or the fine would be £2o. After one year of absence there was the possibility of imprisonment or requisition of property. A Catholic could not own an expensive horse or leave their lodging without notice; Propaganda Fide Archive, Rome, vol. 5-394; and Brian Magee, The English Recusants: A study of the Post-Reformation Catholic Survival and the Operation of the Recusancy Laws (London, 1938), 199.

28 Glickman, The English Catholic Community, 59-64: Penal laws were not routinely enforced. Just a few aristocratic families, including the Gages and the Shelleys, converted to the Anglican Faith in order to advance politically. Catholic estates still flourished during the eighteenth century a time when it was common for property to be designated to Anglican friends in a bid to avoid forfeiture.

29 Bossy, The English Catholic Community; Aveling, The Handle and the Axe, 253-283; Magee, The English Recusants; Tony Claydon and Ian McBride, Protestantism and National Identity, Britain and Ireland, c. 1650-1850 (Cambridge, 1998): During the eighteenth century, the percentage of Catholic gentry decreased, a phenomenon which can be explained by persecution after the Jacobite rebellions of 1715 and 1745, lack of male heirs, and conformation to the Church of England. However, Protestant landowners were affected as much by this decline, due to heavy taxation and constant warfare in the late seventeenth and early eighteenth centuries. Therefore, the extent of the decline of the Catholic gentry should not be overemphasized. Kinoulty, A Social Study, 41, 57: The nobility was defined by certain values and bonds of amity that overcame religious differences. Contacts with Anglicans went beyond religious boundaries and can be seen in tenancy agreements and charity bequests. The Carylls, for instance, attended balls and hunts with their Protestant neighbors, the Dukes of Richmond. Officially, they could not be involved in politics, however the Carylls and the Norfolks had close connections with the Stuart and the Hanoverian dynasties, and they were among the supporters of the petition for Catholic Toleration in 1778. The only way of being utterly accepted was by refusing Catholicism, as did John Shelley in 1716, Sir Cecil Bishop in 1721 and the Earl of Surrey in 1780.

30 WDA, A 41, folio 57, Ragguaglio circa lo Stato dei Cattolici Inglesi (Information about Catholics in England). 
harsh," he wrote, when Catholics were increasingly excluded from social life and severe laws about inheritance and taxation continued to weaken the community. ${ }^{31}$ Caveats notwithstanding, eighteenth-century Catholicism differed much from the recent past. Its practices were relatively tolerated and politically Catholics were no longer seen as "a French fifth column."32 During the second half of the eighteenth century these penal laws became somewhat less harsh and public authorities began to show the community some clemency. ${ }^{33}$ From here, there were new challenges to face, and they were largely economic. The British government had laid claims on the funds of the Mission under the pretext of stopping superstitious practices of Catholicism. In actuality, Challoner's belief was that this new action was in fact a bid to "starve the missioners." ${ }^{44}$ The reality was that the mission needed money, and although pious Catholics supported all the "zealous missionaries," the real problems were faced by the many Catholics who did not have a patron. Religious buildings at this time were few and inadequate; Challoner observed that in London churches were regularly so crowded that "we have to remove from the crowd every people half drowned" (talmente affollate, che ogni giorno conviene levare dalla calca persone mezze affogate). ${ }^{35}$ Help was sought from Rome, but Challoner knew that if granted, it could never have been enough. Needs were many and various; there was an army of diocesan and regular clergy to feed and clothe, as well as the laity to support. Hundreds of families relied on charity for basic sustenance, and the distribution of primary goods such as bread were often left to the charitable nature of the gentry's women, such as "the Countess of Newburgh [that] each Monday and Thursday [distributed bread] in her parish Church of Slindon."36

$31 \quad$ Ibid., "Moreover the Tories are harsh against Catholics, but even though the Whigs are more liberal, they crave properties and the Catholics' fortunes are exposed and easy to catch. Indeed, after the last rebellion all the properties of the gentry involved in it were taken to increase the wealthy of thirteen officials of the party."

C. Johnson, Developments in the Roman Catholic Church in Scotland 1789-1829 (Edinburgh, 1983): the political attitude towards Catholicism changed after the Seven Years' War (17561763), when British supremacy was acknowledged by the other European powers, particularly France and Spain. Therefore, this new context allowed Catholics to obtain some rights: first in England and Ireland, then Scotland in 1791.

Nicholas Schofield and Gerard Skinner, The English Vicars Apostolic, 1688-1850 (Oxford, 2009), 36; WDA, A 41 folio 232, Respecting the Indictments of Priests and Others Under the Penal Laws; There is some evidence of priests being imprisoned until their deaths, but also of trials that ended with the accused being released. During the eighteenth century, authorities began to claim evident proof in legal cases, for instance, if a priest was condemned for holding Mass, witnesses were required to testify as regards to the service.

34 WDA, A 41, folio 136, Breve Relazione.

35 Ibid.

36 Kinoulty, A Social Study. 
The Catholic gentry also provided financial support, donating substantial sums for the clergy as well as the laity. These charitable families became the backbone of a Mission that lacked support; among them the most prominent benefactors were the Norfolks, who in 1758, through the 9th Duke of Norfolk, left " $£ 120$ to be distributed in and about Arundel."37 However, being well aware that the direct use of alms and donations would not fully serve his purposes and answer all the necessities of the Mission, Challoner found a new solution in the stock market. He began to transform part of the funds into bonds, with return rates on his investments being used to support the English Catholic community. Those donations, endowed largely for spiritual purposes such as supporting the missionaries or praying for a donor's soul, became "actions" (shares and bonds) where charitable donations were turned into bank annuities. From here the Catholic Church began to contribute more systematically to the commercial revolution. ${ }^{38}$

The English Catholic community was not disengaged from the imperial economy. Many prominent recusant families such as the Gages, the Blakes, the Fitzgeralds, and the Lynches had interests in the financial world of London and in the imperial markets; all funding enterprises in the Atlantic, the Mediterranean and the East. Many prominent families operated in the empire and through economic participation they established political ties. ${ }^{39}$ Among many, were the Norfolks, active in national politics, close to the Crown and with

37 Ibid, 48. Many missioners were supported and lodged by wealthy families, who were the lynchpin of Catholicism, such as, in the county of Sussex: the Norfolks in Arundel, the Montagues at Cowdray, the Throckmortons at Buckland and the Carylls at West Grinstead. The most important families had just a small percentage of Catholics within their estates, fluctuating between the order of one tenth. By the record of the Catholic converts, it is possible to argue that Protestant servants were not unusual, as in 1726 Mary Newland, daughter of the vicar of Harting accompanied the Catholic Lady Caryll abroad. Moreover, there is no proof that coreligionists received better treatment or favors due to their beliefs, and any specific deals could be explained with reasons other than religion, such as humanitarianism or ties of kinship.

38 WDA, A 41, folio 152, Instructions and Directions for my Executor: In 1765, Mrs Eliot left £24 per annum for the support of Mrs Mary Bright, "deducing two guineas yearly for the managers' trouble." After her death the money would have been disposed by the bishop of the London District. Crispin left £65o: £2oo for the bishop or superior of the Catholic clergy for the use and maintenance of English missioners; £200 to be applied to the education of poor children; and "£1oo or whatever more remains including what may be found in my purse of Crispin's money to be distributed into seven parts, one for each of the six Sardinians chaplains for their respective poor, and the seventh for himself for his own poor." All was turned into bank annuities; Paul, The South Sea Bubble, 118: annuities meant that the investor would have received an annual sum or fee.

39 Gabriel Glickman, "Catholic interests and the politics of English overseas expansion 166o1689," Journal of British Studies 55 (2016): 680-708. 
a strong maritime tradition. In fact, the 1oth Duke of Norfolk was a descendant of the Aylwards, a transatlantic merchant family that between the 168 os and $1710 s$ operated in the most important Atlantic-Mediterranean ports from Cadiz to London. ${ }^{40}$ They participated in Spanish-American trade while extending networks to the British and French Atlantic: a resourcefulness which allowed them to prosper in trade for decades and survive in times of warfare and profound economic and financial change. They were a family where the women too showed business acumen and the ability to successfully invest. Challoner therefore was another factor in a community that had already far reaching and established interests within the imperial economy and his role substantiates this theory.

Challoner's decision to invest in the South Sea Company was not accidental. In fact, after the financial burst of 1720 , the British government began to regulate the market and the company's capital was divided into two halves: the first became annuities, later known as Old, which were managed by the company and assured the proprietors with a more stable capital; the second was called trading capital and fluctuated according to commerce. ${ }^{41}$ Indeed, the South Sea Company had been founded with the intent to reap the profits of the South-American trade, although the British monopoly in those waters never completely succeeded because of fierce Portuguese and Spanish competition and difficulties in procuring African slaves.

Relying on trade was hazardous, and illustrates that since its flawed beginnings, the company had relied on the parliamentary promise to repay through tax revenues, while also attracting lenders with high interest rates of at least 8 percent. After the crisis of 1720 , in order to avoid speculation, the government regulated the market so that investors could then rely on permanent payment, albeit with reduced interest rates of 3 percent during the $173 \mathrm{os}$. According to Challoner's accounts interest rates were usually higher than that percentage. Nevertheless, every six months the yields were good with dividend incomes between $£_{2}$ and $£_{4}$, or sometimes more respectable sums when taken into account that a missioner's annual salary varied between $£_{10}$ and $£_{20}$ or $£ 1$ was enough to "buy many breakfasts." 42

By analyzing the listed transactions, it is notable that all bonds purchased yielded more or less the same percentage of profits, varying only according to the initial input capital. Sums could be anything from a few shillings to a

\footnotetext{
40 Arundel Castle Archive, Aylward Papers (AY).

41 Dickson, The Financial Revolution in England, 181, 272.

42 In the account books it is possible to observe steady incomes of $£_{3}, £_{4}$, £6 each month; WDA, B 1536, Challoner's Ledger.
} 
hundred pounds, and this stability assured a reliable source of income for the Catholic Church. All investments recorded lasted for more than twenty years and were yielded mainly by the South Sea Company stock as well as, at times, the East India Company. Indeed, Challoner's accounts also record East India bonds, although the investments in this company were minimal. Possibly, he thought it safer to diversify his financial operations in order to mitigate losses as the East India Company was the second biggest short term borrower in the stock market after the government itself. ${ }^{43}$ However, as previously mentioned, this stock was in the hands of a few plutocrats whereas after 1720 the South Sea Company was more stable and reliable, so it is not surprising to see the decision of the Vicar to invest mainly in its capital. ${ }^{44}$

By relying also on finance in his efforts to sustain the mission's economic and religious needs, Challoner contributed to sustaining the British expansion, showing a clear commitment towards his community alongside a profound knowledge of financial affairs. He was well aware that as a Catholic personal rewards from public offices were restricted. The community and their patronage were the primary sources of income, combined with a strategic use of the new financial instruments offered by the emerging British economy. Indeed, through Challoner's accounts it is possible to identify sums that were never intended to have charitable purposes but were simply invested in the stock market. Challoner used his knowledge and abilities to center himself within the new expanding economy. He became a skilled man of business, making enough profit to provide for himself as well as sustain charities and, ultimately, his church. The needs were many and varied as Challoner tried to answer the demands of both clergy and laity. ${ }^{45} \operatorname{In} 1745$, a $£ 187$ bond was purchased with the aim of helping the clergy around London. This fund yielded returns ranging from $£_{2}$ to $£_{3}$ each year for over twenty years with dividends every six months

43 Dickson, The Financial Revolution in England, 230.

44 Anne Murphy, "Financial Markets: the Limits of Economic Regulation in Early Modern England," in Mercantilism Reimagined: Political Economy in Early Modern Britain and its Empire, ed. Philip J. Stern et al. (Oxford, 2014), 264-265: The end of the seventeenth century saw the birth of a new financial system that responded to the needs of the British government. The Nine Years' War (1688-1697) and the War of the Spanish Succession (1701-1714) proved longer and more expensive than expected.

45 Dickson, The Financial Revolution in England, 272: After the financial crash of the South Sea Bubble in 1720, the annuities were called New, to differentiate from the Old stock, pre-1720. Among the funds to help the clergy the most prominent were the Norfolk funds invested in Old South Sea annuities: including, the bond of $£_{25}$ O left by Philip Howard, a member of the Norfolk family. 
on May and November (Table 1).$^{46}$ Subscribed funds in the stock market of the time generally varied from $£_{1,000}$ and $£_{5}, 0 \circ 0$. There was always demand for smaller investments up to $£ 500$, whereas more substantial sums reaching as much as £10,ooo made up only a small fraction of the total and were largely owned by "gentlewomen," bourgeois men, clergymen, and famous investors such as Isaac Newton. ${ }^{47}$

Being a safe fixed-interest stock, the South Sea annuities were shared by many investors with charitable purposes. ${ }^{48}$ In order to raise funds, Challoner simply adopted a system employed by the Church of England, whose clergy appeared among the small investors of the East India stock and the South Sea Company. And as there was no official ban on government companies being financed by Catholics, he did invest ${ }^{49}$ His account books accurately list not only the funds and the operations but also from where the money was obtained. In fact, it was the Catholic nobility that assured a constant flow of money which Challoner disposed of efficiently. Donations could vary but usually reached hundreds of pounds, often more, such as the fund of Lady Mary Petre, family of the namesake Bishop, who bestowed $£ 2$,ooo of which $£ 1,500$ was invested in New South Sea annuities and the remainder in Old South Sea annuities - another $£_{5} 00$ was put in India bonds. ${ }^{50}$ The dividend income of this fund was designed for allowing secular priests to be sent abroad for "reformation or improvement" or for those who were "disabled or distracted." ${ }^{11}$ In

46 WDA, A 42-1 Memorandum of Different Sums in my Name in the Stocks 1751-5. WDA, A 41-171, Funds Belonging to the District. WDA, Bishop Petre Fund. Lady Howard, member of the Norfolk family, left $£ 4,000$ to help meet general needs of the missioners and to tend to the poor "within ten miles" of London. This sum was split into various funds and invested in south sea stocks.

47 Paul, The South Sea Bubble, 54-74: Investing in the South Sea Company was advantageous as it was possible to start with small sums and to stop the payments at any time. The company offered to invest in activities other than land or one's own business. Dickson, The Financial Revolution in England, 296-302.

48 Dickson, The Financial Revolution in England, 253-303.

49 WDA, 41-136, English Mission Report: In the 1774 Report to Rome there is mention of a ban from careers in the government companies, such as the Indies and the Royal African Company. However, there is no mention of a ban from company business; Jonathan B. Baskin and Paul J. Miranti, A History of Corporate Finance (Cambridge, 1997), 70: Baskin argues that in England at the beginning of the seventeenth century the end of ecclesiastical bans on usury helped the trading companies to gather capital through financial operations.

50 WDA, A 42-3 Bishop Petre Fund.

51 WDA, A 42-1 Memorandum; WDA, A 41-171, Funds Belonging to the District. In 1751, the Caryll family left three funds valued at around $£ 600$, with the request that the recipient priests would have preached at "Harting and Battle" from 1767 to 1771 ; the priests in those parishes would have received a yearly salary of $£$ 1o. 
TABLE 1 The Norfolks' fund of $£ 187$ and its yearly income

\section{Norfolk's Fund}

\begin{tabular}{|c|c|c|}
\hline Date & Investments & Income $(£ /$ s. $)$ \\
\hline 3 Sept 1746 & Invested in o.s.s. annuities & 187.00 \\
\hline 22 Nov 1746 & Due at Michaelmas & 3.14 \\
\hline 22 June 1747 & Due at Ladyday & 3.14 \\
\hline 19 Nov 1747 & Due at Michaelmas & 3.14 \\
\hline 4 Jun 1748 & Due at Ladyday 1748 & 3.14 \\
\hline 5 Dec 1748 & Due at Michaelmas & 3.14 \\
\hline 5 May 1749 & Due at Ladyday & 3.14 \\
\hline 25 Apr $175^{1}$ & $\begin{array}{l}\text { One year and half and the last quarter } \\
\text { interest due at Ladyday }\end{array}$ & 11.00 \\
\hline 25 Sept 1752 & $\begin{array}{l}\text { Bill for one year given to Mr B. due at } \\
\text { Ladyday }\end{array}$ & 6.11 \\
\hline 12 Nov 1753 & $\begin{array}{l}\text { Bill given to Mr P. due at Michaelmas, one } \\
\text { year and half interest }\end{array}$ & $9 \cdot 16$ \\
\hline 12 Dec 1754 & $\begin{array}{l}\text { Bill received from Mr W. for one year due at } \\
\text { Michaelmas } 1753\end{array}$ & 6.11 \\
\hline 25 Nov 1756 & $\begin{array}{l}\text { Bill due at Michaelmas 1756, one year } \\
\text { interest }\end{array}$ & 6.11 \\
\hline 7 May 1757 & Received by Mr W. Due at Ladyday & $3 \cdot 5$ \\
\hline 16 Nov 1757 & Received and due at Michaelmas & $3 \cdot 5$ \\
\hline 1o May $175^{8}$ & Due at Ladyday & 3.5 \\
\hline 13 Nov $175^{8}$ & Due at Michaelmas & 2.16 \\
\hline 12 May 1759 & Due at Ladyday & 2.16 \\
\hline 7 May 1760 & Due at Ladyday & 2.16 \\
\hline 8 May 1761 & Due at Ladyday & 2.16 \\
\hline 21 Nov 1761 & Due at Michaelmas & 2.16 \\
\hline 15 May 1762 & Due at Ladyday & 2.16 \\
\hline 15 May 1763 & Due at Ladyday & 2.16 \\
\hline 12 Nov 1764 & Due at Michaelmas & 2.16 \\
\hline
\end{tabular}


one record, a sum of $£ 1,450$ was invested in India bonds and South Sea trading stock with income left for private occurrences and the general good of the clergy - bequeathed by an unknown benefactor who desired clergymen to pray for him and his family on the anniversary of their deaths. ${ }^{52}$ Indeed, Catholics would often donate money as a penalty or "as a means of atonement"; what is unusual however, is that the benefactor in this case remained anonymous, an uncommon act at a time when patrons cherished public recognition and the social worth of their compassionate acts. ${ }^{53}$ In fact, Challoner's ledger books record only two anonymous donors. ${ }^{54}$ Irrespective of their purpose or sources, such donations became the pillars of the entire religious structure as well as that of the wider non-religious community. Why so many bequeathed money is not clear, but in Catholic circles it is feasible to assume that charity was seen as a means of being a good Christian and to gain spiritual rewards in the afterlife, perpetuating medieval practices. ${ }^{55}$ Moreover, the wealthy gentry saw in these acts of compassion an opportunity for honor. In fact, all recorded funds in Challoner's ledger are listed under the names of their donors-offering the chance to promote economic and family interests and further ideological positions. Whether Challoner organized special events, such as dinners or ceremonies, to raise money is not known, but it is clear that donors were often found through personal and religious relations. Patrons from among the gentry were possibly persuaded by Challoner's charisma as he was widely regarded "a legend to his people," renowned for his severe spirituality and frugal lifestyle. ${ }^{56}$ The community trusted him as "The Venerable" with his penitential regime and donated him some of their savings. In return he did not forget to cherish their friendship and honor their memories with more mundane means "such as a $£_{1}$ ring for a banker's wife. ${ }^{57}$ In his books the bishop did not list other sources of income; therefore, one could hypothesize that without the investment opportunities created by imperial and financial expansion, the Catholic mission would have failed. Challoner's ledgers listed investments from the

52 Ibid.

53 Andrew, Philanthropy and Police, 81.

54 WDA, A 42-1 Memorandum. The stock market sustained Catholics not only in England but also in the American colonies. A certain Sir JJ left $£ 4,000$ for 100 missioners in Pennsylvania. Initially, it was £4o per missioner but later was reduced to £2o because half the sum was invested in East India annuities.

55 Brian Pullan, "Catholics, Protestants and the Poor in Early Modern Europe," Journal of Interdisciplinary History 35, no. 3 (2005): 441-456.

56 Eamon Duffy, Challoner and his Church: A Catholic Bishop in Georgian England (London, 1981), 1-26.

57 WDA, B 1536 Challoner's Ledger. Ben-Amos I.K., The Culture of Giving, Informal Support and Gift Exchange in Early Modern England (Cambridge, 2010), 45-81. 
early 1730s until his death in 1781. Each fund usually yielded profits for more than twenty years, and, in some cases, Challoner inherited his investments as well as passing others on to his own successors following his death. This practice was extremely common as funds could be kept in the stocks for more than thirty years. (Indeed, Challoner registered an investment in the Old South Sea annuities on June 16,1739 , and again on May 26,1775$) .58$

What is fascinating is that Challoner not only supported the clergy but sustained wide ranging work, from providing bread and candles to sponsoring scholarship. Indeed, the profits generated by the fund of Mrs Brent were used between 1760 and 1763 to apprentice two young men, Thomas Edward and Titus Hubbert, as shoemakers. ${ }^{59} \mathrm{~A}$ few years later the money was used to support a Hospitium and to meet the costs of a school in which to educate "young ladies who may otherwise be lost in the wide world." ${ }^{60}$ Indeed, in 1758 Challoner mentioned a young lady with no family who was in danger of losing her virtue, her religion or both, if left to seek her own fortune. He set up a small fund with the profits of $£_{5} \mathrm{O}$ which had been invested by her father before his death in the hope that it would pay her a "little matter yearly."61 Other money was distributed for needy gentlemen and to maintain a young

$5^{8}$ WDA, A 41-143, The Brent Fund. The fund of Mrs Brent yielded initially £2o per annum, whereas in 1775 the income was reduced to $£_{15}$ a year. Challoner was the only trustee. Ultimately, it yielded an annual sum of $£_{14}$, " $£_{7}$ due at Ladyday" and " $£_{7}$ at Michaelmas." Still in 1779 the fund yielded money for the relief of prisoners. Specifically, £2oo was used for: £1o for a prisoner detained at Newgate, other £1o for the discharge of Ann Tailor from the Marshalsea, £2o transferred to the green purse for the service of prisoners, $£_{20}$ to Suddel for releasing Mrs Reaves from the Marshalsea, and other $£_{20}$ for other prisoners. On November 3, 1779, £40 remained, half to release J. Hussey from the "Poultry" and $£_{15}$ to release Leigh Welch.

59 WDA, A 41 folio 143, The Brent's Fund.

6o WDA, B 1536 Challoner's Ledger, Trusts in Bishop Petre's Hands: These funds are also listed in the document about the London District in January 1762. Lady Abergavanny left a fund of $£ 1,000$ for prayers and priests. John Dowentwater left a fund with an income of $£_{13}$ per annum, to be disposed by the Bishop. Richard Canning left ten £1oo bonds for a priest in Essex. Apollonia Yate bequeathed money for a Hospitium. Hunt left a fund of £2oo in bank annuities to help the priests at Chauson in Bedfordshire, but as there was no priest or congregation, the fund was reallocated to Shefford. Christopher Cross left an income for prayers for his soul. The small fund in the Chapter trust was of $£_{3} 6$ in South Sea annuities and $£_{12}$ in South Sea trading stock. Mrs Anna Maria Risdon left $£_{400}$ in the Chapter trust, which was invested in the French India Company. The income was meant to be used by a certain Smith during his life and then further used for a priest's maintenance. Burton left the income of his funds to Smith to maintain priests. Ballasis left $£_{150}$ to Bishop Petre in French bonds with the income assigned for Masses for her sister's soul. WDA, A 41-113 Proposal for Asylum for Young Maids, 1770.

61 WDA, B 1536 Challoner's Ledger. 
boy in the school of Hammersmith (Tables 2 and 4). ${ }^{62}$ Through such actions, the Vicar Apostolic consumed himself in sustaining his community with his investments contributing to provide the financial foundation of the Catholics' spiritual and mundane needs. His account books even document funds used to help the poor using money generated by his deals in Old and New South Sea annuities. ${ }^{63}$ Once any income was received, Challoner made sure to respect the wishes of the donors no matter how specific. Often they would require their money be spent to care for the needy but only through "a secular priest of the Douai College." 64 When not specified, money was used to sustain the clergy with their daily expenses, such as travel to another parish, payment for performing a service, praying for the donors' souls, or covering Mass on behalf of another colleague (Table 3). ${ }^{65}$ The profits were used for diverse purposes, for instance in 1758 , from a fund of $£_{3}$,ooo invested in East India annuities, the profits yielded were spent purchasing lamps, for housekeeping services, or calls for which priests did not have enough cash. ${ }^{66}$

Throughout his career, Challoner showed outstanding managerial abilities; he was able to control hundreds of investments and assured that the money would be well spent according to the wishes of the benefactors. As above mentioned, these requests could be as specific as requests for masses to be recited twice per week for the souls in Purgatory, to help a certain priest in Essex, or

62 Amy M. Froide, "The Religious Lives of Singlewomen in the Anglo-Atlantic World: Quaker Missionaries, Protestant Nuns, and Covert Catholics," in Women, Religion, and the Atlantic World (1600-180o), ed. Daniella Kostroun et al. (Toronto, 2009), 61-78: The Hammersmith School was founded in 1669 as a covert nunnery. Officially, it was a boarding school where young Catholic ladies were educated. Some of the women would eventually join the religious community. The school survived until the late eighteenth century, and in 1795 was left to the Benedictine nuns who had fled France during the French Revolution.

63 Dickson, The Financial Revolution in England, 181: After 1720, the South Sea stock was divided in annuities, a fixed-interest stock, and trading capital, a stock subject to trade's fluctuation.

64 WDA, A 41, folio 143, The Brent Fund.

65 WDA, A 41, folio 143, The Brent Fund: White, Fuller, and Webb were the priests mentioned by Challoner, whereas the last secular clergyman was Blevin. The funds were left by Mrs Mary Brent and a Rob Hill.

66 WDA, B 1536 Challoner's Ledger: The Mission was formed by embassies' chaplains, seculars and regulars who responded to the ambassadors and not to the Vicars Apostolic. In addition, there was a group of "free missioners" and gentry chaplains who served the gentry houses and the poor, independent from the Mission. Of the incomes: $£_{5}$ was used for the services of Bishop Benjamin Petre at the Sardinian Chapel, $£_{1}$ was given to the Earl of Stafford for a ring, £8 to Hodgson "Apothecary and physics," $£ 55$ to Cross and his wife Ann Dale for housekeeping, and $£ 6$ for one year's wage. $£ 37$ went to Greenwell for funeral charges and inventory. The priest was Sheppard, and the fund yielded profits from 1758 to at least 1765 . Ultimately, a priest's salary usually ranged around $£ 2$ o per year. 
TABLE 2 Mrs Gilbert left many funds. This is one of $£_{5}$ oo invested in the South Sea Company, in both New and Old annuities.

\section{Mrs Gilbert's fund}

\begin{tabular}{lll} 
Date & $£$ 50o in the South Sea books & Income $(£)$ \\
\hline 12 Aug 1745 & New annuities & 10 \\
11 Nov 1745 & Old annuities & 11 \\
22 Nov 1746 & Old annuities & 12 \\
4 Dec 1747 & New annuities & 20 \\
9 June 1749 & Old annuities & 44 \\
\hline
\end{tabular}

TABLE $3 \quad £ 1,125$ turned into 25,593 French livres at the rate of 22 livres, 15 sols the pound sterling. With this money Challoner and his agent bought twelve shares in the French Company. This benefaction was part of the Brent's fund.

\section{Hill's benefaction}

Date

to support the "Shefford library." ${ }^{7}$ Challoner was aware that the gentry aimed first to sustain their local parishes; however, with each fund he also tried to answer the many and various needs of the Mission. He responded to the most diverse necessities, showing a keen eye for business. Ultimately, he was an acute observer of the stock market and kept accurate and detailed accounts of investments as they were influenced by the ebb and flow of financial trade. Such donations sustained the entire religious structure, and investment in companies other than British was not uncommon. Indeed, Challoner several times scribbled investments sur les fosses in Paris and in the French market he possibly relied on networks established during his stay at Douai College; in fact

67 WDA, B 1536 Challoner's Ledger, Trusts in Bishop Petre's Hands. 
TABLE 4 The Hammersmith School fund was formed by various donations. This is the income for the year 1759 .

Hammersmith School's fund

\begin{tabular}{llc} 
Date & Investments & Income $(£ /$ s. $)$ \\
\hline 7 Feb 1759 & From $£ 1,1$ oo Royal Assurance & 16.10 \\
14 Feb 1759 & From £100 East India stock & 10.10 \\
& From £950 in New South Sea annuities & 14.5 \\
12 May 1759 & From £6oo Old South Sea annuities & 9.00 \\
5 Aug 1759 & From $£ 1,100$ Royal Assurance & 16.10 \\
19 Nov 1759 & From $£ 6$ oo Old South Sea annuities & 9.00
\end{tabular}

a fund of $£ 253$ was listed in his testament "to be drawn out of the hands of the procurator of the College." ${ }^{68}$ However, his books do not shed further light on these foreign investments and only once record an investment in the French India Company - a company which proved unprofitable before shutting down in 1769 due to mismanagement, corruption, and inability to control the East Indian trade and to tap into international networks. ${ }^{69}$

His accounts accurately list funds and benefactors, controlling more effectively the various financial operations within the Mission. Strict supervision was essential in making the system work. ${ }^{70}$ It is not surprising that the management of these funds often caused disputes, such as in 1745 when a couple of hundred pounds left by the Norfolk family was contested between

68 WDA, A 41-152 Instructions and Directions for my Executor. Challoner died on January 12, 1781 and was buried in Milton Parish Church. His body was then moved to Westminster Cathedral in London.

69 Furber Holden, Rival Empires of Trade in the Orient, 1600-1800, 185-229.

70 The money was intended for charitable purposes, for the laity or the clergy but at times it is not clear how much in need the clergy and their relatives were. Indeed, in 1767 the notable sum of £1oo was given to Lady Lucy Talbot, who was related to Challoner's assistant, and a further $£_{40}$ o was paid to the wife and son of George Petre, family of his predecessor. These were notable sums if considered that Challoner paid for four months lodging with $£_{20}$, £2 was enough for serious medical expenses, and £1 could "buy many breakfasts." Money was given to Mrs Wright's mistress as a Christmas present. Mrs Wright's husband was the banker with whom Challoner dealt most of the time and was surely a trusted friend. Indeed, he was also acquainted with the previous Vicar, Petre, who in 1757, left a fund for a female school. 
Bishop Stonor and the chapter of his church. ${ }^{71}$ Stonor belonged to the Midland District and had worked with Challoner for many years, the pair becoming close friends and colleagues who strove to secure the power of the vicars against the regular orders and the Jesuits in the mission. They were both known for their rigid discipline and spirituality, so much so that in 1765 - equally horrifiedthey attempted to find the Italian culprit that had introduced 250 copies of the book Ode a Priapo into the country. In any case, regarding the dispute, Challoner liaised with Stonor and the clergy to resolve the issue and see the fund returned to the Norfolk family. ${ }^{72}$

I I I

The Financial Revolution provided opportunity to accumulate capital through financing of the national debt. Investing in the Bank of England, and the East India and South Sea companies became common across the country, and the Catholic Church followed suit. Challoner had inherited a system of support from his predecessors based on the stock market and set up to meet growing needs as support from Rome was lacking. It was thanks to his vision and ability that over the next forty years he would go on to greatly improve it. Furthermore, Challoner's books show indeed how his operations were not isolated, and reliance on the stock market to support charities was not only a feature of his district but of the whole Mission. Indeed, his predecessor Bishop Petre had adopted the same strategy, leaving significant funds in the district's accounts, and before him, Bishop Leyburn (1688-1703) and Bishop Giffard (1703-1734) each purchased bonds in various companies. In the Midland and Western districts, the Talbots also invested-Stonor among them. ${ }^{73}$ The Talbots belonged to a wealthy Catholic family and were able to dispose of copious funds. ${ }^{74}$ Among the administrators of the funds was also Walton, assistant of the Northern District and a prominent benefactor, who often invested in South Sea annuities. It is possible therefore to extend these financial practices to the English Catholic Church as a whole: a hypothesis suggested by the financial hardship so often lamented in the papers of the mission and how Rome was never effective in its response to the many petitions sent to further new financial policies,

71 WDA, A 42-1 Memorandum of Different Sums in my Name in the Stocks 1751-5. WDA, A 41-171, Funds Belonging to the District.

72 WDA, A 41, folio 53, Letter of Richard Challoner to his agent in Rome on December 17, 1765.

73 WDA, B 1536, Challoner's Ledger.

74 Bossy, The English Catholic Community, 15o. One of the many bishops in the Talbot family, James, would become Challoner's successor. 
particularly in the 173os. The Catholic Church in England could not rely on government endowments as the Catholic faith was being penalized.

That Catholics were still marginalized is perhaps further illustrated in evidence that the various vicars routinely hid their Catholic identities when investing, often resorting to aliases. Mr Leyburn, Vicar Apostolic of the Western District, used the false name of Bradley, and Challoner's accounts show funds often registered under the name of Richard Fisher. ${ }^{75}$ Resorting to false identities was perhaps a necessary precaution, as the Catholic Church officially forbade involvement in finance, and it was only in the 178 os that the Church introduced new legislation allowing money lending and new income possibilities. ${ }^{76}$ However, maybe as Dickson suggests, Catholic investors primarily concealed their identities for business secrecy and tax evasion. ${ }^{77}$ What we know is that although the bishops did not interfere with each other's jurisdictions, they cooperated within their districts by either lending or borrowing money among themselves. For instance, $£_{3} 00$ from Leyburn's fund was paid to Bishop Petre to purchase shares in the French India Company in the name of Richard Fisher. This action suggests that Challoner was not unique in his work but using a strategy widely adopted by the Church as a whole. Challoner had tapped into already established financial networks and improved the system, introducing a more coherent organization and listing accurately all the investments and benefactors alongside detailed records of how the money was being used. For more than thirty years in his ledger books, Challoner posted, in the form of debts and credits, all the monetary transactions of his community. He reorganized the Mission's financial network and improved the functionality of his predecessors' creation, adopting the economic strategies introduced by other vicars, while tapping into the financial system of charitable corporations. Indeed, Protestant charities were among the stockholders of the South Sea Company, and like the Catholic Mission's funds, their investments varied between $£_{500}$ and $£_{5}, 000$. Therefore, Challoner simply followed his Protestant counterparts, moving within a Protestant economy under the rules of the

\footnotetext{
75 Bishop Leyburn is referred to as Bradley in the document about the funds belonging to the London District in January 1762.

76 Walsh, The South Sea Bubble and Ireland, 27.

77 Alison Weir, Henry VIII, King and Court (London, 2002), 365: Bishop John Fisher was executed for Treason in June 1535 during the English Reformation. He refused to acknowledge Henry viII as head of the Church and his divorce from Catherine of Aragon. Challoner most likely selected the name of John Fisher (1469-1535) to commemorate a bishop that chose to die instead of betraying his Catholic beliefs. Dickson, The Financial Revolution in England.
} 
British financial system in a move which would finance some of the needs of the Catholic Church and contribute to it playing an active role in the economy.

In 1774, a report of the Catholic Mission was sent to Rome, complaining about Catholic marginalization and exclusion from public life. It lamented Catholics' penalties such as double land tax and exclusion from public offices and careers in the directories of maritime companies. In highlighting how this penal legislation was not enforced, it echoed a previous report published in 1746 that deplored the condition of Catholics who were tolerated but with limited political rights; they could practice commerce, "but they would not enrich themselves!" Perhaps they did not, but they surely participated..$^{78}$ Indeed, English Catholics were being still officially prosecuted; penal laws were still in effect and emancipation was not yet complete. However, the fear of persecution had faded and public attitude towards English Catholics had become less severe. Although the public was not yet fully tolerant, formally, small concessions were granted and political integration did not seem an entirely foreign concept although it had not yet been completely accomplished. ${ }^{79}$ Officially, Catholics were still restrained from engaging in English political and civil life, but these liabilities did not bar Catholic investments in government companies and in the stock market where any subscriber was welcome, Protestant or not. ${ }^{80}$ Indeed, among the public creditors of the British government, there were aristocrats, bourgeois, women, clergymen, and non-Conformists, suggesting that when the financial situation became an urgent priority, religion was no longer

78 WDA, 41 folio 136, English Mission Report; WDA, A 41 folio 57, Ragguaglio circa lo Stato dei Cattolici Inglesi.

79 C. Haydon, Anti-Catholicism in Eighteenth Century England, c. 1714-80, A Political and Social Study (Manchester, 1993): In Britain the main national Catholic threat was from Jacobitism, which faded after the defeat of 1745; Claydon and McBride, Protestantism and National Identity; Thomas O'Brien Hanley, The American Revolution and Religion: Maryland 1770-1800 (Washington, DC, 1971): during the American Revolution, recruitment needs saw the British Army opened to Catholics, a concession granted to also avoid possible allegiance between Catholics and revolutionaries in the British colonies; Johnson, Developments in the Roman Catholic Church in Scotland 1789-1829.

$80 \quad$ Kinoulty, A Social Study: Prominent Catholic families had also political roles, such as the Norfolks; WDA, 41-136, English Mission Report; Aveling, The Handle and the Axe, 256: Aveling argues that the fifth Duke of Norfolk, Edward Howard, was a man of electoral weight, supporter of the Hanoverian Kings. 
relevant. ${ }^{81}$ The role of English Catholics, whether clergy or laymen has been briefly acknowledged by the historiography. But Challoner's accounts offer a new insight into this group of public creditors in which Catholics, both religious and secular, played an active role. They clarify in what ways the money was used, how timely investments contributed to support the Catholic Church in England and how a prosecuted religious minority participated in the imperial economy.

Challoner strengthened and revived the faith, and at the same time remained remarkably committed to the financial life of his country. He knew his community had suffered decline and was well aware that noble patrons were the lynchpin of his Mission. Alms and donations were turned into stocks as one of the means of gathering further resources, and ensuring profitable investments was important to sustaining the Mission's economic viability. This evidence calls into question the extent to which the Catholic community was marginalized and examines the concept of exclusion and integration, highlighting how new financial instruments were open to everyone. The dwindling of the Catholic community and its declining influence nationally remained a valid interpretation. These processes did not entail sectarianism or social ostracism, but simply led to a rejuvenated role of a community within the modern English economy. A body of men, women, and clerics invested in the Empire, modernizing the Church's institutional strategies and supporting commercial expansion. Catholics' knowledge of financial markets contributed to sustaining the Catholic Church and the British government. Indeed, Challoner managed his church and financed the government companies for more than forty years, until his death in $1781 .{ }^{82}$ His records suggest that this system was in place at the origin of the Mission in the late seventeenth century and between his actions and those of his predecessors was almost a century of economic inclusion in which Catholics seized the opportunities offered by the new fiscal-military economy.

This article has considered the contribution of the English Catholic community to commerce and finance, helping us rethink the role of Catholics within the economic growth of the country and thus within the nation. The eighteenth century saw profound change when a new economic, political, and cultural scene evolved. It was the beginning of a rational age, with the rise of a powerful

81 Dickson, The Financial Revolution.

82 WDA, A 41, folio 152 Instructions and Directions for my Executor. Challoner ensured for the Vicar Apostolic role an annual income of £8o. 
Protestant Britain, and decline of Catholic France and Spain. ${ }^{83}$ Scholars have argued how different factors had a role in Catholic emancipation; in 1745-1746 the Stuart-Jacobites were completely defeated and after the Seven Years' War (1756-1763), with France and Spain acknowledging British superiority, Catholic forces were finally overcome nationally and internationally. Throughout the eighteenth century religious issues had become less urgent for the British government which was more concerned with the economy and influenced by new enlightened ideas. Furthermore, during the American Revolution British recruitment needs opened the army to Catholics, a concession also granted to avoid a possible allegiance between Catholics and revolutionaries in the British colonies. Therefore, political and economic contingencies made the time ripe for Catholics' social rehabilitation. Since the late seventeenth century, Catholics' strength has been in the ability to adapt to the new economic and political changes. In this new age, the fledgling empire needed economic support; the identity of the moneylender was not relevant to the government, and the new commercial economy made religion a less urgent priority. The quest for money offered an opening and Catholics seized it. Arguably, the age of mercantilism and the interest of the "moneyed men," combined with fading threats of continental Catholicism, paved the way for the Relief Act of 1778 , the first step towards British Catholic emancipation.

83 Haydon, Anti-Catholicism in Eighteenth Century England, c. 1714-80; Claydon and Mc Bride, Protestantism and National Identity; Thomas O'Brien Hanley, The American Revolution and Religion: Maryland 1770-1800 (Washington, DC, 1971); Johnson, Developments in the Roman Catholic Church in Scotland 1789-1829. 